sued nationally and the pay tends to be very low. But the administration of the EC grants is relatively straightforward - a 20 per cent tax charge to the national research council and a 10 per cent charge to the university and researchers do well financially, earning as much as four times the fellowship stipend or twice that of an equivalent permanent research worker.

British universities are also trying to make arrangements at a local level to avoid paying fellows the same salaries as department heads. For example, the University of Warwick holds back between a quarter and a half of the grant for travel and publishing (leaving the fellows very much better off than their bench mates), but the University of Cambridge was told that it could not ask fellows to return some of their cash to the university department for equipment or laboratory consumables. Salaries are exempt from tax in some universities.

Of host countries with the largest number of fellowships, only in Denmark is the programme working relatively smoothly. All fellows there are given their money on a contract basis, and their take-home pay does not deviate significantly from local levels.

But even if the question of payments is answered, a second problem is bound to arise. Researchers will naturally favour the countries where they will be best off, putting countries whose tax and social security laws force them to offer low salaries at a distinct disadvantage.

How could such an ambitious and wellfunded scheme have foundered so disastrously on such obvious and predictable points? The European Commission has been criticized for refusing to become involved in solving the problems of the individuals it funds, but it is not the only culprit. The tortuous democratic processes of the European Communities must also share the blame, with proposals designed by the commission bounced to and fro among the European Parliament, the commission and the European Council of Ministers. The original proposal, for example, included provision of bench fees within the fellowship money, but it was eliminated to conform to the wishes of the parliament to avoid any direct support of research.

The commission erred in accepting salary figures from each member state without consulting those who must administer the grants, but its hands are tied to some extent by the decisions of the Council of Ministers. Although living costs and normal salary deductions were taken into account, the resulting scales are badly flawed.

The commission is working with member states to resolve the immediate problem of salaries, but a long-term solution to the disparity within and between countries will require a political decision. In the meantime, European scientists are trying not to let their frustrations override their enthusiasm for the principles behind the programme.

Alison Abbott

\title{
Congress searches for new role for energy laboratories
}

Washington. Two US lawmakers have proposed different solutions to the pressing problem of finding a civilian role for the research laboratories operated by the Department of Energy (DOE). One would encourage all DOE laboratories, not just those conducting weapons research, to cooperate with industry in fields ranging from the environment to health, advanced manufacturing, space and high-performance computing. The other would ask DOE to narrow the mission of individual laboratories and, perhaps, even to close some of them.

The first bill, introduced on 2 March by the chairman of the Senate Energy and Natural Resources committee, would require the laboratories to spend at least 10 per cent of their research dollars on cooperative projects with industry, in line with recommendations from both the Bush and Clinton administrations. The DOE spends about $\$ 6.6$ billion a year on research and development at more than 20 laboratories scattered around the country. The legislation, introduced by Senator J. Bennett Johnston (Democrat, Louisiana), would also simplify the paperwork and other requirements for making deals with private companies.

Not surprisingly, the directors of DOE's primary nuclear weapons research laboratories - Lawrence Livermore in California and the Los Alamos and Sandia laboratories in New Mexico -- support any attempt to diversify their business now that the Cold War has ended. In a November letter to justelected President Clinton, they offered their services in supercomputing, environmental monitoring and other fields where "science and technology can help make a difference" to the US economy.

Pete Lyons, the deputy director for energy and environmental research at Los Alamos, says that his centre would like eventually to spend as much as 20 per cent of its budget on partnerships with industry, a figure that Clinton mentioned during his campaign as a ceiling for such efforts. More than that, says Lyons, would be a mistake: "You can't sustain a laboratory on technology transfer."

In fact, critics of this approach claim that turning the energy laboratories into hightechnology 'job shops' without specific responsibilities is a recipe for disaster. Instead, they say, the laboratories should have a few clearly defined 'core missions' against which their performance can be measured.

US Representative George Brown (Democrat, California), the chairman of the House Science, Space and Technology committee, has suggested that weapons research might be consolidated at one or two laboratories, with the others being converted pri- marily to civilian uses such as improving the environment. Brown was expected this week to introduce a bill that would require DOE to report on how it might accomplish this costcutting and consolidation.

Brown may also ask for the creation of a laboratory closure commission similar to that established to decide which US military bases should be closed. But the politics of closing any government facility - particularly if it involves cutting high-technology jobs - may prevent this. Even realigning personnel is politically difficult, says Edward Frieman of the Scripps Institution of Oceanography, who chaired a task force last year that advised DOE on the future of its laboratories. Erich Bloch, former director of the National Science Foundation and a senior fellow at the nonprofit Council on Competitiveness, which conducted a similar study last year, says that the three weapons laboratories are "unkillable".

Not that Brown, or anyone else, has pinpointed which laboratories, if any, should be closed. But with some 700 federally run laboratories and a diminishing need for defence-related research, the government has a problem of oversupply. Meanwhile, agencies such as the Department of Commerce intend to create new centres to feed the Clinton administration's desire to transfer technology from government to the private sector. Next week, Energy Secretary Hazel O'Leary will testify before Johnston's committee about her vision for the laboratories.

Tony Reichhardt

\section{India moves ahead on rocket contract}

New Delhi. India has selected four private and two government companies to start making engine components using the cryogenic rocket technology that it is purchasing from Russia over the objections of the United States.

The \$80-million contract with Glavkosmos will enable India to build engines to power the upper stage of a rocket to launch 2.5-tonne satellites into a geostationary orbit. The United States has imposed a two-year ban on exports of space technology to the Indian space agency because it considers the contract to be a breach of an international agreement to prevent the spread of nuclear technology (see Nature 357, 99; 1992), but the Russian president, Boris Yeltsin, assured Indian officials last month during a visit that his country would abide by the agreement signed by the former Soviet Union. The first launch is planned for 1995
K.S. Jayaraman 